\title{
投手の投球動作の評価法に関する研究
}

○岩瀬弘和, 村田厚生（広島市立大学）

\section{A Study on the Evaluation of Pitching Motion}

Hirokazu Iwase and Atsuo Murata (Hiroshima City University)

\section{1.はじめに}

近年, 高速ビデオメラを使った 3 次元映像 解析法によって投手のピッチング動作に関する 研究が行なわれているが, それらは各関節部位 の角度を分析した動作特性の分析にとどまって いる。

本研究では, 投球動作における人体モデルを 作成し,体の各部位のエネルギーとボールの初 速との関係を調べ, 初速に大きく寄与している 部位を明らかにした。また, 投球腕の角度や上 胴の傾き, ひねり角などを求め, 球種によって 違いがあるかを調べた。さらに, 投球腕と反对 側の有のばらつきと初速, コントロールとの関 係を明らかにした。そして,これらを指標とし た投手の評価について考察を行なった。

\section{2. 実㒭方法}

\section{1 被験者}

被験者は実業団硬式野球部の投手 6 名, およ び高校硬式野球部の投手3名であり，そのうち 右投手は6名，左投手は3名であった。また，被 験者の身長は $1.76 \pm 0.06 \mathrm{~m}$, 体重は $73.1 \pm 9.6 \mathrm{~kg}$ (平均値士標準偏差) であった。

\section{2 投球動作撮影}

高速ビテオカメラ (ナック製) 2台を使って， 投手の投球動作をサンプリング周波数 $200 \mathrm{~Hz}$ 撮影した。分析システムとして, 3 次元動作解 析ソフト Frame DIAS（電機計測販売製）を使用 した。Frame DIAS はビデオで撮影された画像 から各ポイントを入力していくビデオデダイ ズ方式をとっている。

十分な投球練習の後, 被験者の身体の各関節 部位にテーピング用のテープを貼り,それらの 動きが撮影できるように, 2 台の高速ビテオカ メラをそれぞれ，投手から見て投球方向の左右 約 $45^{\circ}$ の位置に設置した。各被験者とも, 持つ
ている球種を 5 球ずつ投球させた。撮影したビ デオから測定点 15 ポイントの動きをDLT 法 (Direct Linear Transformation Method) により算 出した。座標系は, 投球方向に対して右方向を $\mathrm{X}$ 軸，投球方向をY軸，鈶直方向を $\mathrm{Z}$ 軸とした。 そして, 踏出脚の接地時からボールのリリース 時までのデータについて解析を行なった。

\section{3 算出項且}

1）投球腕と反対側の肩のばらつき

投球動作における支点は投球腕と反対側の肩 であり, 支点のばらつきが大きいと初速が落 ち，コントロールも定まらない1)。この支点の ばらつき SFD（Shoulder Fulcrum Dispersion）を

$$
\begin{aligned}
S F D & =\sum_{i=1}^{N}\left\{\left(x_{i}-\bar{x}\right)^{2}+\left(y_{i}-\bar{y}\right)^{2}\right\} \\
\bar{x} & =\sum_{i=1}^{N} x_{i} / N, \bar{y}=\sum_{i=1}^{N} y_{i} / N \quad(N: \text { テー夕数 })
\end{aligned}
$$

と定義し,この值が小さいほど支点のばらつき が少ないと判断した。ここで $\mathrm{x}_{\mathrm{i}}, \mathrm{y}_{\mathrm{i}}$ はデジタイ ズした3次元データをxy平面に投影した個々の テータを表す。

2）人体モデルによる各部位のパワー

3次元動作解析ソフトFrame DIASの分析機能 を使って人体モデルを作り, 投球腕の前腕と上 腕, 踏出脚の下腿と大腿および胴体の5つの部 位のパワー $(\mathrm{kgw} \cdot \mathrm{m} / \mathrm{s})$ を算出した。人体モデ ルの作成には阿江ら ${ }^{2)}$ の身体部分質量係数を利 用した。

3）投球腕と体幹の動作

投球腕における肩関節の内転・外転, 水平屈 曲・伸展, 内旋・外旋及び时関節の屈曲・伸展 角を算出した。また, 上胴の後傾・前傾角, 右 傾・左傾角, 及び体幹の前方・後方ひねり角を 算出した。これらは宮西ら ${ }^{3)}$ の方法に基づいて 算出した。 
表 1 支点のばらつきと初速の相関係数

\begin{tabular}{c|ccccc}
\hline 被験者 & sub 1 & sub 2 & sub 3 & sub 4 & sub 5 \\
\hline 相関係数 & -0.614 & -0.947 & -0.502 & -0.143 & -0.771 \\
\hline \hline 被験者 & sub 6 & sub 7 & sub 8 & sub 9 \\
\hline 相関係数 & -0.303 & -0.602 & -0.283 & -0.264 \\
\hline
\end{tabular}

\section{3. 実篌結果および考察}

\section{1肩のばらつきと初速との関傒}

支点のばらつき $S F D$ とボールの初速との相関 係数を表 1 に示す。この結果から，個人差はあ るが, 支点のばらつきとボールの初速には負の 相関があり,ばらつきが大きいほど初速が落ち るといえる。

しかし, 支点のばらつきとコントロールとの 関係については, 1 元配置の分散分析の結果, ストライクの場合とボールの場合で支点のばら つきに有意差はみられなかった。

\section{2 人体モデルによる各部位のパワーと初速と} の関係

投球腕の前腕, 上腕, 踏み出し足の下腿, 大 腿及び胴体の 5 つの部位のパワー $(\mathrm{kgw} \cdot \mathrm{m} / \mathrm{s})$ を独立変数, 初速 $(\mathrm{m} / \mathrm{s})$ を従属変数として重回 帰分析を行なった結果, 上腕との相関が 1 番大 きく(相関係数 0.73$)$, 前腕との相関が 1 番小さ かった（相関係数-0.124）。前腕のパワーを除い たときの重回帰式は,

初速 $=0.134 \times$ 上腕 $+0.176 \times$ 下腿 $-0.130 \times$ 大腿 $-0.009 \times$ 胴体 +22.763

となり, 重相関係数は 0.95 であった。

このことから, 上腕と下腿にパワーを持たせ ることが, 初速を高めることにつながることが 分かる。

3.3 投球腕の角度之体幹角度の球種による違い

各被験者について, 球種ごとに投球腕の肩内 外転, 肩水平屈伸, 肩内外旋, 时屈伸角及び上 胴の前後傾角, 左右傾角, 体幹のひねり角を算 出した。角度データについては踏出脚の接地時 からボールのリリース時までのデータを 3 次ス プライン関数で補間し，その区間を $100 \%$ とし たときの $1 \%$ ごとのデータを求めた。

このデータについて球種間の違いを調べたと ころ, どの場合もほとんど差は見られなかった ので, 各被験者, 各球種ごとに規格化された $1 \%$ ごとのデータの平均を求めた。

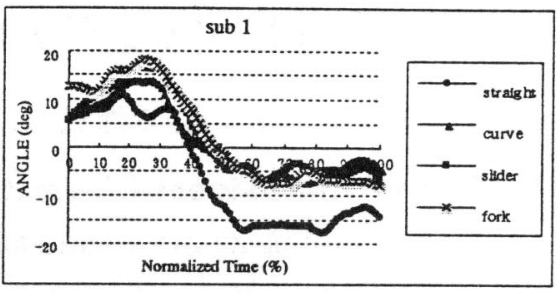

図 1 球種により肩内外転角の異なる例

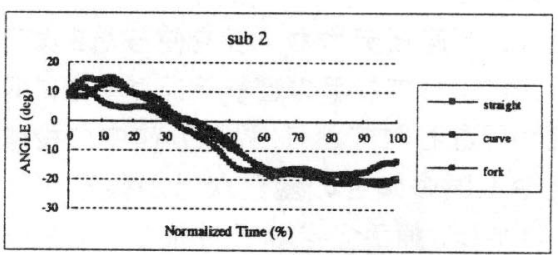

図2 球種による肩内外転角の違いの無い例

平均化されたデータについて球種による角度 の相違を調べたところ, 上同や体幹の角度には どの被験者も球種による違いはほとんど見られ なかったが，投球腕の肩や肘の角度は球種に よって違いのある被験者と無い被験者がいた。 それらの例を図 1 及び図 2 に示す。図 1 は高校 野球の控え投手であり，図2の被験者は実業団 野球で活躍している主力投手である。このこと から,評価の高い投手は異なる球種を投げると きにもフォームが変わらないことが分かる。

\section{4. おわりに}

投球時の支点となる投球腕と反対側の肩のば らつきを数式で定義し, 肩のばらつきが大きい と初速が落ちることが確認できた。また, 投球 動作における人体モデルから, 投球腕の上腕と 下腿のパワーが初速に大きく寄与していること が明らかになった。さらに，評価の高い投手ほ ど投球腕の肩や肘の角度や上胴の傾き, ひねり 角などが球種によってほとんど変わらないこと が確認できた。

\section{参孝文献}

1) 比佐仁:「NOMO」を見て，考える(II), Baseball Clinic, 10, pp.48 50, 1995

2）阿江通良 他: 日本人アスリートの身体部分慣 性特性の推定, バイオメカニズム11, pp.23-32, 1992 3）宮西智久 他: 大学野球選手における速投およ び遠投動作の 3 次元的比較研究, 体育学研究, 40 , pp.89-103, 1995 